Article

\title{
Evaluation of the Water Conservation Function of Different Forest Types in Northeastern China
}

\author{
Xueliang Zheng, Lihua Chen *, Wenyan Gong, Xia Yang and Yingli Kang \\ School of Soil and Water Conservation Beijing Forestry University, Beijing 100083, China \\ * Correspondence: Lihuachen@bjfu.edu.cn; Tel.: +86-010-6233-6108
}

Received: 25 June 2019; Accepted: 25 July 2019; Published: 28 July 2019

\begin{abstract}
Water conservation is an important function of forest ecosystems, but it is still unclear which forest types function best in this regard. We investigated the water conservation function indicators including the water-holding rate of branches and leaves $\left(\mathrm{BL}_{\mathrm{wr}}\right)$, water-holding capacity of litter $\left(\mathrm{L}_{\mathrm{wc}}\right)$, water absorption rate of litter $\left(\mathrm{L}_{\mathrm{wr}}\right)$, soil infiltration rate $\left(\mathrm{I}_{\mathrm{r}}\right)$, soil and water content (SWC), soil water storage (SWS), and soil organic matter (SOM) accumulation of five forest types (Larix gmelinii forests, Pinus koraiensis forests, Robinia pseudoacacia forests, Pinus tabulaeformis forests, and mixed forests) and evaluated them using the gray correlation method (GCM). The results indicate that the BLwr of five stands in the study area varied from $18.3 \%$ to $33.5 \%$. The SWC and SWS of the R. pseudoacacia stand were $13.76 \%$ and $178.9 \mathrm{~mm}$, respectively, which was significantly higher than that of the other stands $(p<0.05)$. The SOM was similar for the R. pseudoacacia $(0.23 \%)$, mixed forest $(0.22 \%)$, and L. gmelinii $(0.22 \%)$ sites. The $\mathrm{BL}_{\mathrm{wr}}, \mathrm{L}_{\mathrm{wc}}, \mathrm{L}_{\mathrm{wr}}, \mathrm{SWC}$, and SWS values of broad-leaved tree species were higher than those of the mixed species, followed by those for coniferous tree species. Soil infiltration rate followed the order L. gmelinii $>$ P. koraiensis $>$ mixed forest $>$ P. tabulaeformis $>$ R. pseudoacacia. Based on our results, the R. pseudoacacia stand had the highest water conservation ability, while the lowest performance was found for the P. tabuliformis site. This suggests that, in order to enhance the water conservation function of forests in northeastern China, the focus should be on the establishment of R. pseudoacacia forests.
\end{abstract}

Keywords: water conservation; function; gray correlation method; forest type

\section{Introduction}

Forest ecosystems are the most widely distributed, complex, and abundant terrestrial ecosystems. They have numerous hydrological functions, such as water conservation, water regulation and flood mitigation, and water quality improvement [1-3]. Several ecological issues, such as frequent floods, soil erosion, and land desertification, are closely related to the degradation of forest ecosystems, thereby impeding the water conservation function of forests [4,5]. In forest ecosystems, precipitation is redistributed in the tree, shrub, grass, litter, and soil layers, resulting in soil water conservation, groundwater replenishment, reduced surface evaporation, and river runoff regulation [6-8]. The water conservation function of forests is greatly influenced by species composition, stand structure, soil type, and external disturbances $[9,10]$. Most studies on forest water conservation have focused on the role of vegetation and the relationship between forest soil and water conservation [11-14], while studies on the water conservation capacity of different forest types are scarce. Evaluating the capacity of forests to conserve water is a research hotspot, and numerous measurement methods have been developed in the last 100 years [15]. However, so far, there is no clear definition of the water conservation function of forests, mainly because it is perceived and measured differently by different authors [15]. However, different measurement methods inevitably have their own advantages, characteristics, and limitations. Multivariate regression and the comprehensive water storage method are applicable at the regional 
scale of small watersheds, albeit with complex calculations [16,17]. The Gray correlation method is widely used as a relatively simple and reliable analysis method [18]. The results of this method are accurate and can be used to analyze the development trend of a system. In addition, there is no requirement in terms of sample number, and a typical distribution law is not needed because the amount of calculations is relatively low [19-21].

The mountainous area of Eastern Liaoning is a typical seasonal dry area in China. Precipitation is unevenly distributed (about $70 \%$ of precipitation occurs in June-September), with serious water shortage [22]. Against the background of a warming climate, these water shortages will be aggravated, restricting the water conservation function of vegetation in this area [22]. Only by adapting to this arid environment, plants can maintain their ecological benefits and functions. Larix gmelinii, Pinus koraiensis, Robinia pseudoacacia, Pinus tabulaeformis, and mixed forests are widely distributed in the eastern Liaoning Mountains [22]. After long-term natural selection and co-evolution, they have shown a strong ecological adaptability. However, we do not know which forest type has the highest water conservation capacity, making it necessary to compare these forests, incorporating global climate change data. In this study, based on the mechanism and definition of the water conservation function of forest ecosystems, from the perspectives of canopy water holding, litter water holding, litter water absorption, and soil water storage, the water conservation capacities of different forest stands in northeastern China were evaluated using the gray correlation method.

\section{Materials and Methods}

\subsection{Study Sites}

The study was conducted in Monkey Stone Forest Park, which is located on the Zhaojia Forest Farm, Xinbin Manchu Autonomous County, Liaoning Province (Figure 1). It is a typical glacial landform with a total area of $1935 \mathrm{hm}^{2}$ and a slope of $10-36^{\circ}$. The average elevation of the study location is $520 \mathrm{~m}$ above sea level. The region is characterized by a seasonal continental climate in the northern temperate zone, with a large temperature difference between mornings and evenings. The average annual temperature is $7{ }^{\circ} \mathrm{C}$, with an average annual rainfall of $790 \mathrm{~mm}$ and an average annual amount of sunshine of $2262 \mathrm{~h}$. The forests in the study area are mainly secondary forests and plantation forests. The soil type is tidal brown soil, with an average soil thickness of $120 \mathrm{~cm}$. Most of the plantations are coniferous forests dominated by Pinus koraiensis (17.3\%), Pinus tabulaeformis (16.4\%) and Larix gmelinii (14.8\%), while the secondary forests are mainly composed of broad-leaved species common in northeastern China, such as Robinia pseudoacacia (14.1\%), Quercus mongolica and Ulmus pumila. The shrub and herb layers are distinct and include species of the genera Euonymus and Syringaoblata.

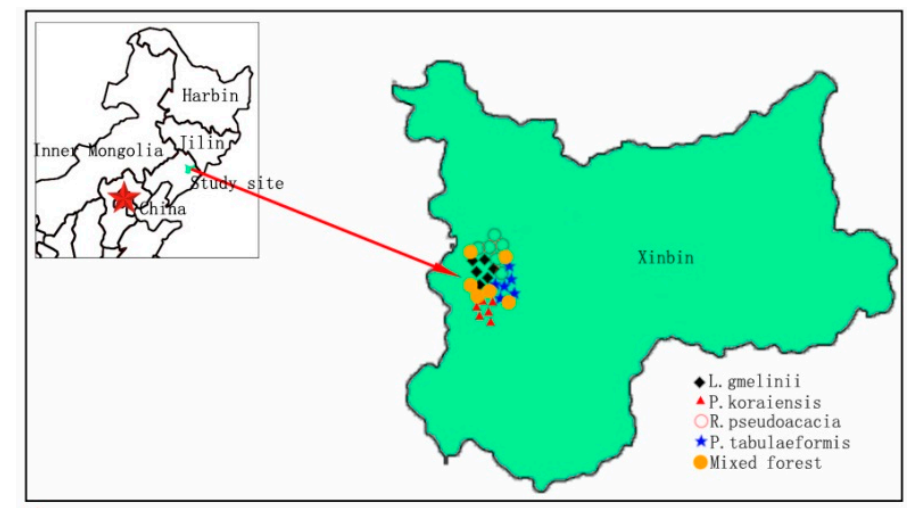

Figure 1. Geographic location of the study area. 


\subsection{Experimental Design}

In June-September 2018, we selected three typical sunny days of each month. For sampling, we selected five typical water conservation forests with the highest proportion, namely $P$. koraiensis forests, R. pseudoacacia forests, P. tabulaeformis forests, L. gmelinii forests, and mixed forests. In each forest type, six standard plots with an area of $20 \times 20 \mathrm{~m}$ were established, and in each plot, three litter sampling plots with an area of $30 \times 30 \mathrm{~cm}$ were randomly set up (Table 1 ). The sample plots were relatively close and have the same average soil depth. The age, height, DBH and other information of trees were investigated according to the Forest Health Survey Manual [23].

Table 1. Basic information of the vegetation species in the community.

\begin{tabular}{cccccc}
\hline Plot Size/m & Vegetation Species & Category & Forest Density/hm & Average Height/m & DBH/cm \\
\hline \multirow{3}{*}{$20 \times 20$} & L. gmelinii & Coniferous & 926 & $11.16 \pm 1.67$ & $20.60 \pm 2.83$ \\
& P. koraiensis & Coniferous & 1117 & $21.18 \pm 1.58$ & $31.59 \pm 3.91$ \\
& R. pseudoacacia & Broad-leaved & 1201 & $12.79 \pm 1.39$ & $15.87 \pm 2.03$ \\
& P. tabulaeformis & Coniferous & 1086 & $13.60 \pm 1.28$ & $17.59 \pm 3.05$ \\
& Mixed forest & $/$ & 959 & $/$ & $/$ \\
\hline
\end{tabular}

\subsection{Determination of Water-Holding Capacity}

\subsubsection{Branches and Leaves}

In each selected standard sampling plots, we collected six fresh branches with diameter of 0.3-1 $\mathrm{cm}$ and annual leaves, respectively, and weighed them $\left(M_{0}\right)$ [23]. The samples were placed in a standard cloth bag $(750 \mathrm{~mL})$, which was then placed into water until saturation. Subsequently, the material was removed from the bags and the free water on the surface was soaked up with filter paper, removing all water droplets. The samples were then weighed again, and the weight was recorded as $M_{1}$; the water-holding capacity was calculated as follows:

$$
\mathrm{M}=M_{1}-M_{o}
$$

\subsubsection{Litter}

After establishing a sampling plot of $0.3 \times 0.3 \mathrm{~m}$, the thickness of the litter layer within the plot was measured with a steel tape ruler [23]. Subsequently, the living vegetation was removed, then the non-decomposed and decomposed litter layers were collected, weighted, and stored in a net bag. The samples were transported to the laboratory and oven-dried at $65^{\circ} \mathrm{C}$ to constant weight. Based on the dry weight, the litter stock was calculated, and the dried litter was immersed in water. After $0.5,1$, $1.5,2,4,6,8,12$, and $24 \mathrm{~h}$, the litter was taken out, excessive water was removed, and the samples were weighed again to determine the water-holding capacity for each time period. After $24 \mathrm{~h}$, the mass was basically unchanged, and therefore, the water-holding ratio after $24 \mathrm{~h}$ was considered the maximum water-holding capacity. The water holding capacity $\left(\mathrm{W}_{\mathrm{c}}\right)$ and water holding ratio $(\mathrm{C})$ can be expressed as follows:

$$
\begin{gathered}
\mathrm{W}_{\mathrm{c}}=W_{m}-W_{o} \\
\mathrm{C}=\frac{W_{m}-W_{o}}{W_{o}} \times 100 \%,
\end{gathered}
$$

where $W_{m}(\mathrm{~g})$ and $W_{o}$ are the wet mass of litter soaked for $24 \mathrm{~h}$ and the drying quality of the litter, respectively.

\subsection{Measurement of Soil Infiltration Rate}

In all five forest types, we randomly selected three sampling points. In each point, we used an inner iron ring $(10 \mathrm{~cm}$ in diameter, $30 \mathrm{~cm}$ in height) and an outer ring $(20 \mathrm{~cm}$ in height, $30 \mathrm{~cm}$ in height) to penetrate the soil of the $0-5-\mathrm{cm}$ layer [24]. During the measurement, a certain amount of water was 
added between the outer and the inner ring (with a water depth of $1 \mathrm{~cm}$ ), and subsequently, water was added to the inner ring (the water volume was assessed based on the scale of the small steel ruler). When the water depth in the inner ring had decreased by $0.5 \mathrm{~cm}$, water was added to reach $1 \mathrm{~cm}$, and we recorded the time (in minutes) it took to reach the $1-\mathrm{cm}$ water mark.

\subsection{Soil Moisture and Nutrient Determination}

From all five sites, in undisturbed soil patches, we sampled the soil layer 0-10, 10-20, 20-40, 40-60, $60-80$, and $80-100 \mathrm{~cm}$ by a soil auger, taking three replicate samples per layer. The volume of each sample was $400 \mathrm{~mL}$. A part of the samples was homogenized in aluminum boxes and transported to the laboratory to determine the water content, while the other part was used for the measurement of soil organic matter. The soil organic matter content was determined via the potassium dichromate volumetric method [25], while for the assessment of the soil water content (SCW), the soil was oven-dried at $105^{\circ} \mathrm{C}$ until constant mass [26], and the percentage of the lost mass in the sample was calculated. Soil water storage was determined as follows:

$$
\text { SWS }=\text { SWC } \times \text { VWS } \times \text { L, }
$$

where SWC is the soil water content, VWS is the volume weight of the soil, and L is the soil thickness.

\subsection{Using the Gray Correlation Method (GCM) to Evaluate the Water Conservation Capacity}

First, we calculated the absolute value of the difference between reference sequence $\left(\mathrm{Y}_{0}\right)$ and the comparison sequence $\left(Y_{i}\right)$ in each corresponding point as follows:

$$
\begin{gathered}
\Delta \mathrm{i}(k)=\left|\mathrm{Y}_{0}(k)-Y_{i}(k)\right| \\
\mathrm{Y}_{0}=\left\{\mathrm{Y}_{0}(1), \mathrm{Y}_{0}(2), \mathrm{Y}_{0}(3), \ldots \ldots, \mathrm{Y}_{0}(n)\right\} \\
\mathrm{Y}_{i}=\left\{\mathrm{Y}_{i}(1), \mathrm{Y}_{i}(2), \mathrm{Y}_{i}(3), \ldots, \mathrm{Y}_{i}(\mathrm{n})\right\}, i=1,2,3, \ldots, m .
\end{gathered}
$$

Here, $Y_{i}$ and $Y_{0}$ are the comparison series and reference series, respectively. Each test indicator (maximum value) is expressed in the value of the reference series.

When using this approach, the original data are standardized, and the evaluation of each index must be translated into actual values, according to the reference series data. The influence of each index size should be eliminated [27].

We used the formula $\mathrm{Y}_{i}(k)=$ reference data/original data sequence to perform non-dimensionalization, restoring the data to the $[0,1]$ interval.

Subsequently, we determined the correlation coefficient using the difference between second-order maximum $\left(Y_{i}(k)_{\max }\right)$ and the second-level minimum $\left(Y_{i}(k)_{\min }\right)$, as follows:

$$
\xi_{i}(k)=r \mathrm{Y}_{0}(k), \mathrm{Y}_{i}(k)=\frac{\operatorname{minmin} \Delta_{i}(k)+\rho \operatorname{maxmax} \Delta_{i}(k)}{\Delta_{i}(i)+\rho \operatorname{maxmax} \Delta_{i}(k)}=\frac{\Delta_{\min }+\rho \Delta_{\max }}{\Delta_{0, i}(k)+\rho \Delta_{\max }},
$$

where, $\xi_{\mathrm{i}}(k)$ and $\mathrm{Y}$ and $\mathrm{Y}_{i}$ are the reference curve and the relative value of the $k$ point, respectively. The $\mathrm{Y}$ sequence is positive in $1 \leq i \leq \mathrm{m}$ and at the $k$ point, just at $\Delta 0, i(k)$ is the absolute value, and $\rho$ is the resolution coefficient ranging from $0-1 . \Delta \max$ and $\Delta \min$ are the maximum and minimum values of the absolute difference in each point, respectively. Here, $\rho$ was artificially set to 0.5 . The formula of $r_{i}$ can be expressed as

$$
r_{i}=\frac{1}{n} \sum_{k=1}^{n} \xi_{i}(k)
$$

where $\xi$ and $r_{i}$ are the gray correlation coefficient and the degree of the gray correlation, respectively. 
The coefficient of variation $\mathrm{W}_{i}$ can be calculated as follows:

$$
W_{i}=\frac{\mathrm{r}_{i}}{\sum \mathrm{r}_{i}}
$$

Subsequently, we calculated $\mathrm{G}(k)$ with the correlation degree value:

$$
G_{k}=\sum_{k=1}^{n} \xi_{i}(k) W_{i}
$$

where, $\mathrm{G}(k)$ is the gray comprehensive evaluation value.

\subsection{Statistical Analysis}

We used the statistical software package SPSS 16.0 for data analysis. The means and standard deviations of each group were calculated by descriptive statistics. First, the SOM and SWC ( $n=$ 18 for each soil stratum) were analyzed by using two-way ANOVA, with soil depth and treatment as the independent factors. We also used one-way ANOVA to test the effects of $\mathrm{BL}_{\mathrm{wr}}, \mathrm{L}_{\mathrm{wc}}, \mathrm{L}_{\mathrm{wr}} \mathrm{I}_{\mathrm{r}}$, SWC, and SWS on all treatments. If necessary, the water-holding rates of feasible water sources were compared using Least Significant Difference

\section{Results and Discussion}

\subsection{Water-Holding Rates of Branches and Leaves of Different Forest Types}

The water-holding capacity of branches and leaves is an important index reflecting the water conservation capacity of the canopy, determined by canopy density and water-holding capacity together $[28,29]$. In this sense, the greater the water-holding capacity of branches and leaves, the better the water conservation capacity [30]. The water-holding rates of the branches and leaves from the five forest types in the study area varied from 18.3 to $33.5 \%$ (Figure 2 ), with the highest levels $(p<0.05)$ for the R. pseudoacacia forest $(33.5 \%)$ and the lowest $(p<0.05)$ levels for the P. koraiensis forestt $(18.3 \%)$, with a difference of $45.37 \%$. The P. tabulaeformis and L. gmelinii forests showed $34.62 \%$ and $41.19 \%$ lower values, respectively, than the R. pseudoacacia forest. The water-holding rates followed the order R. pseudoacacia $>$ mixed forest $>$ P. tabulaeformis $>$ L. gmelinii $>$ P. koraiensis, indicating that broad-leaved tree species have a higher water-holding capacity than coniferous tree species, most likely because of the larger leaf area. Similar results have been observed previously [31]. Harris et al. have also demonstrated that the water-holding capacity of broad-leaved trees in the same research area was greater than that of conifers [32]. The water absorption capacity of branches and leaves was not only related to their size, but also to their water absorption characteristics [33]. Rough leaf surfaces have a stronger water holding capacity than smooth ones [34].

\subsection{Water-Holding Capacity and Litter Rate under Different Forest Types}

The water-holding capacity of the litter showed a good relationship with time. Within $2 \mathrm{~h}$ of initial immersion, the values increased rapidly (Figure 3); after this, the rates decreased, and the water-holding capacity basically reached saturation after $24 \mathrm{~h}$. Generally, partly decomposed litter has a higher water-holding capacity than fresh litter in the same stand. The maximum water-holding capacity of decomposed and partly decomposed litter ranged from 5.04 to $12.35 \mathrm{~g} / \mathrm{kg}$ and from 8.57 to $16.40 \mathrm{~g} / \mathrm{kg}$, respectively. The average maximum water-holding capacity of partly decomposed litter was $56.75 \%$ higher than that of non-decomposed litter. Among the non-decomposed litter, the maximum value was $12.35 \mathrm{~g} / \mathrm{kg}$, which was significantly higher than that of the other stands $(p<0.05)$. The lowest value was found for the P. tabulaeformis stand $(5.04 \mathrm{~g} / \mathrm{kg})$, which was significantly lower than that of the other stands $(p<0.05)$. The water-holding capacity followed the order mixed forest $>$ L. gmelinii $>$ R. pseudoacacia $>$ P. koraiensis $>$ P. tabulaeformis. 


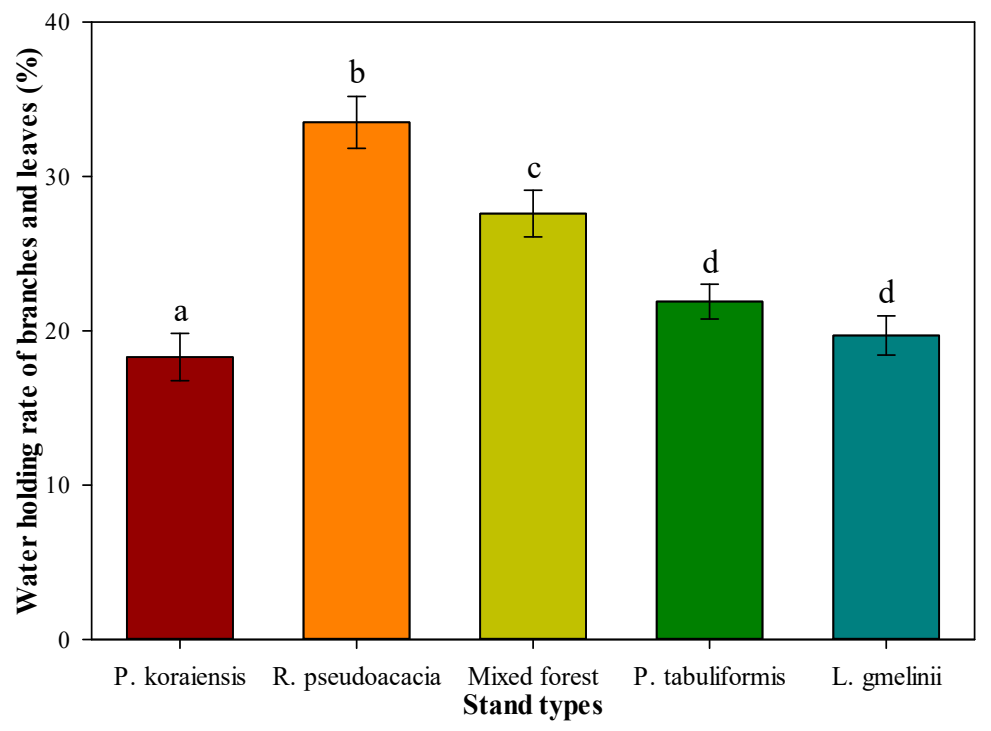

Figure 2. Mean $( \pm S D)$ Water-holding rates of branches and leaves under different forest types in northeastern China. Different letters indicate significant differences in water-holding rates among the different forest types. Bars indicate error bars.

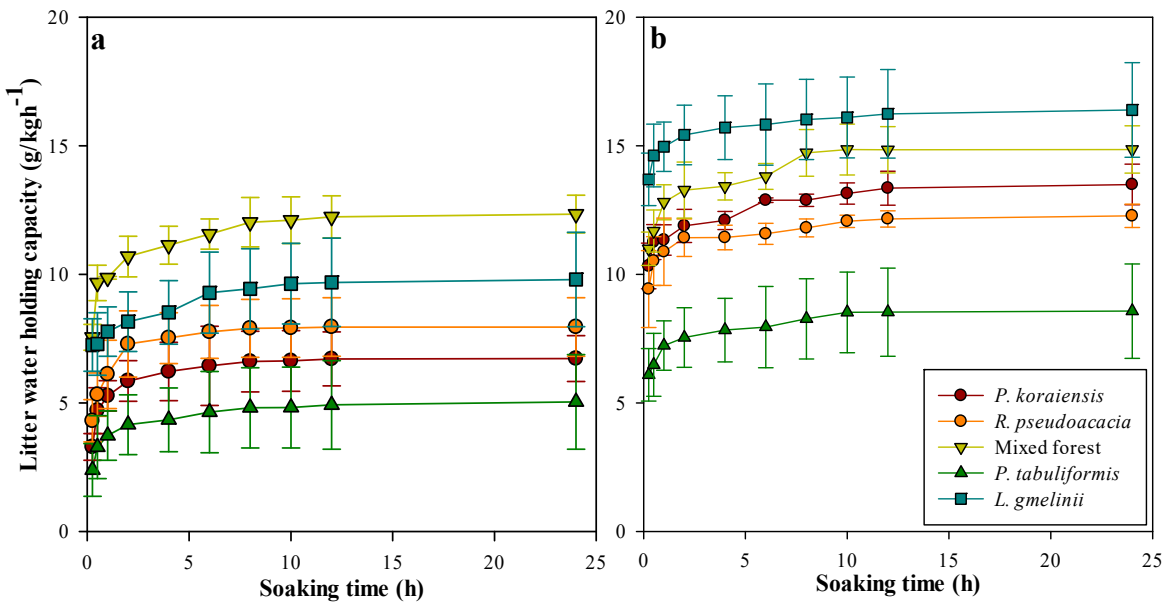

Figure 3. Mean $( \pm S D)$ Water-holding capacity of litter under different forest types in northeastern China. $(\mathbf{a}, \mathbf{b})$ represent the water-holding capacity of undecomposed and partly decomposed litter, respectively.

The relationship between litter water absorption rate and time could be expressed as an inverse J-shaped curve (Table 2). The water absorption rate of litter changed most rapidly within the first $2 \mathrm{~h}$ of immersion, with a subsequent rapid decrease (Figure 4). The decline slowed down gradually within 2-10 $\mathrm{h}$ and stopped after 10-24 $\mathrm{h}$. When the litter was immersed in water, the water absorption rates differed among the five forest types. With a prolonged immersion time, the same trend was observed for water uptake, indicating that the water-holding capacity of litter had reached saturation. In general, the water absorption rate of partly decomposed litter was higher than that of non-decomposed litter. The maximum rates ranged from 9.56 to $29.01 \mathrm{~g} \mathrm{~kg}^{-1} \mathrm{~h}^{-1}$ and from 24.37 to $54.81 \mathrm{~g} \mathrm{~kg}^{-1} \mathrm{~h}^{-1}$ for non-decomposed and partly decomposed litter, respectively. Among the partly decomposed litter samples, the maximum water absorption rate of L. gmelinii litter was $54.81 \mathrm{~g} \mathrm{~kg}^{-1} \mathrm{~h}^{-1}$, which was significantly higher than that of the other stands $(p<0.05)$. The maximum water absorption rate of P. tabulaeformis litter was significantly lower than those of the other stands $\left(24.37 \mathrm{~g} \mathrm{~kg}^{-1} \mathrm{~h}^{-1}\right.$; $p<0.05)$. The water absorption rate followed the order L. gmelinii $>$ mixed forest $>$ P. koraiensis $>$ R. pseudoacacia $>$ P. tabulaeformis. Water-holding capacity and water absorption rate of litter are related to litter characteristics and reserves. Dunlop et al. state that the decomposition degree of 
litter in larch and mixed forest stands was higher than that in other forests [35]. The thickness and decomposition degree of litter are the main factors that determine the water absorption capacity of litter [32,36]. In addition, dryness and microbial activity of litter are also important factors affecting its water absorption capacity [37].

Table 2. Relationship between $\mathrm{Q}(\mathrm{xy}), \mathrm{V}(\mathrm{xy})$, and $\mathrm{t}(\mathrm{xy})$ in different forest types in northeastern China.

The $\mathrm{Q}, \mathrm{V}$ and $\mathrm{t}$ represent water-holding capacity, water absorption rates and time, respectively.

\begin{tabular}{ccccc}
\hline Litter Layer & Stand Type & Relationship between $\mathbf{Q}$ and $\mathbf{t}$ & $\mathbf{R}^{\mathbf{2}}$ & Relationship between $\mathbf{V}$ and $\mathbf{t}^{\mathbf{R}^{\mathbf{2}}}$ \\
\hline \multirow{5}{*}{ Undecomposed layer } & P. koraiensis & $\mathrm{Q}=196.60 \ln (\mathrm{t})+1358.0$ & 0.89 & 0.99 \\
& R. pseudoacacia & $\mathrm{Q}=366.05 \ln (\mathrm{t})+3275.5$ & 0.91 & $\mathrm{~V}=1319.50 \mathrm{t}-0.86$ \\
& Mixed forest & $\mathrm{Q}=281.81 \ln (\mathrm{t})+2771.8$ & 0.93 & $\mathrm{~V}=3347.00 \mathrm{t}-0.89$ \\
& P. tabuliformis & $\mathrm{Q}=159.33 \ln (\mathrm{t})+1021.2$ & 0.93 & $\mathrm{~V}=2741.10 \mathrm{t}-0.90$ \\
& L. gmelinii & $\mathrm{Q}=227.27 \ln (\mathrm{t})+2702.3$ & 0.95 & $\mathrm{~V}=989.82 \mathrm{t}-0.85$ \\
& P. koraiensis & $\mathrm{Q}=155.64 \ln (\mathrm{t})+2558.8$ & 0.96 & $\mathrm{~V}=2683.90 \mathrm{t}-0.93$ \\
\hline \multirow{5}{*}{ Partly decomposed layer } & R. pseudoacacia & $\mathrm{Q}=110.31 \ln (\mathrm{t})+3454.4$ & 0.83 & $\mathrm{~V}=2544.00 \mathrm{t}-0.95$ \\
& Mixed forest & $\mathrm{Q}=220.05 \ln (\mathrm{t})+3024.9$ & 0.95 & $\mathrm{~V}=3038.00 \mathrm{t}-0.95$ \\
& P. tabuliformis & $\mathrm{Q}=113.59 \ln (\mathrm{t})+1376.2$ & 0.97 & 0.99 \\
& L. gmelinii & $\mathrm{Q}=173.58 \ln (\mathrm{t})+3055.4$ & 0.93 & $\mathrm{~V}=3004.30 \mathrm{t}-0.99$ \\
& & & & 0.99 \\
& & & 0.99 \\
& & & 0.99 \\
\hline
\end{tabular}

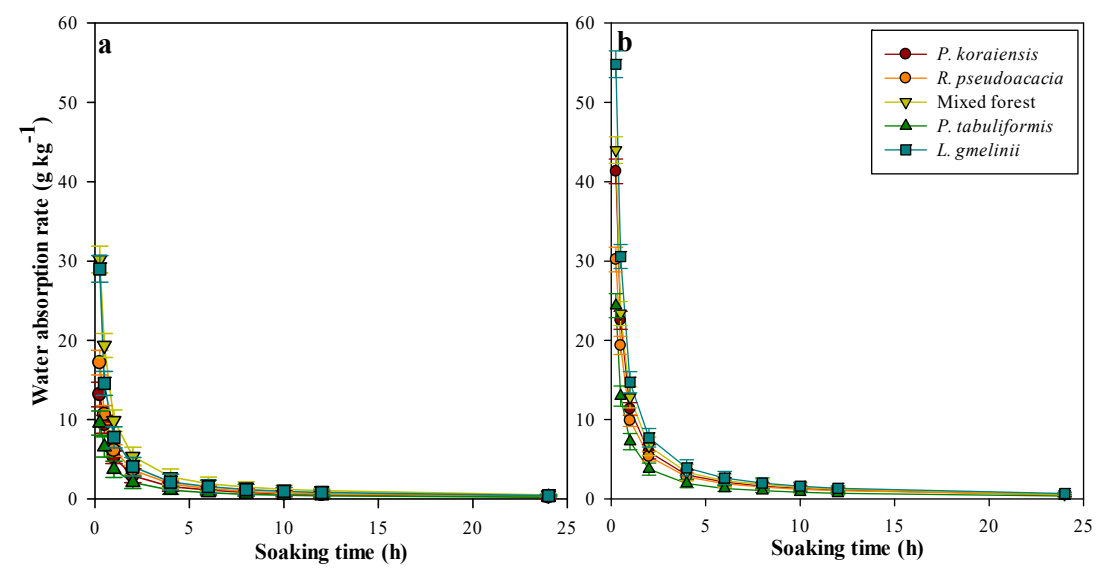

Figure 4. Water absorption rates of litter under different forest types in northeastern China. (a,b) represent the water-holding capacity of undecomposed and partly decomposed litter, respectively.

\subsection{Soil Infiltration Rates under Different Forest Types}

Initial infiltration rate, steady infiltration rate, and average infiltration rate are three commonly used indicators to evaluate soil infiltration performance [38]. However, besides the physical and chemical properties of soil, the initial infiltration rate of soil varies significantly with the initial soil water content [39]. Therefore, to eliminate the influence of initial soil water content, the steady infiltration rate was used for comparison in this study. The variation of the infiltration rate with infiltration time followed an "inverse J" curve (Figure 5). Across all forest types, the values were highest within the first $20 \mathrm{~min}$ of soaking, with a subsequent rapid decline. After 20-120 min, the rates tended to be stable. The rate for L. gmelinii was the highest $\left(9.45 \mathrm{~mL} \mathrm{~min}^{-1}\right)$ and was significantly higher than that of the other forest types $(p<0.05)$, while the lowest rate was observed for $R$. pseudoacacia $\left(4.49 \mathrm{~mL} \mathrm{~min}^{-1}\right)$. The rate of L. gmelinii was 2.10 times that of the rate observed for $R$. pseudoacacia. The mixed forest site showed a rate of $6.38 \mathrm{~mL} \mathrm{~min}^{-1}$, which was 25.17 and $32.53 \%$ lower than that of P. koraiensis and L. gmelinii, respectively, and 42.0 and $3.0 \%$ higher than that of R. pseudoacacia and P. tabulaeformis, respectively. The rates followed the order L. gmelinii $>$ P. koraiensis $>$ mixed forest $>$ P. tabulaeformis $>$ R. pseudoacacia. These differences among the different forest types may be due to the different contents of soil pores and soil aggregates. Dunkerley et al. have demonstrated that the more compact the soil, the smaller its porosity and the lower the steady infiltration rate [40]. With a higher aggregate content, the number of soil pores increases, resulting in improved soil ventilation and permeability and in enhanced soil stability, preventing the formation of soil surface crusts [41]. The aggregate content was highest in the soil from the L. gmelinii site, which therefore had the highest seepage stabilization rate. 

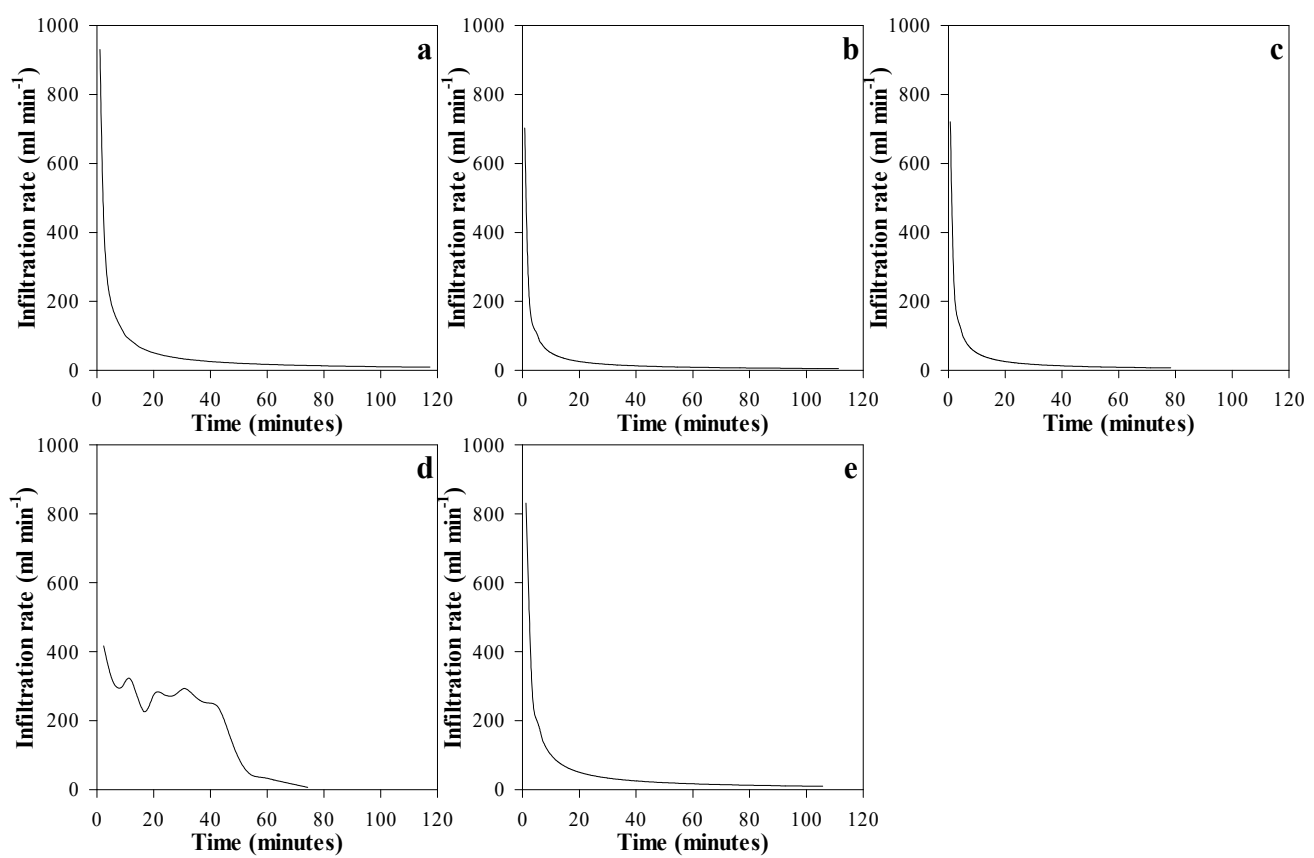

Figure 5. Soil infiltration rates of different forest types in northeastern China. (a-e) represent the P. koraiensis, R. pseudoacacia, mixed forest, Pinus tabuliformis, L. and gmelinii stands, respectively.

\subsection{Soil Water Content and Storage under Different Forest Types}

Soil water content is mainly affected by precipitation, soil evapotranspiration and surface cover [42]. The soil water content differed significantly among the five forest types (Figure 6). The average soil water content of the R. pseudoacacia stand was $13.76 \%$, which was significantly higher than that of the other stands $(p<0.05)$. The soil water contents of $P$. koraiensis and P. tabulaeformis were $10.25 \%$ and $9.56 \%$, respectively, and 25.46 and $30.49 \%$ lower than that of R. pseudoacacia, most likely because $P$. koraiensis and P. tabulaeformis are evergreen species, and in these stands, the litter layer was relatively thin and hardly decomposed, while Q. variabilis, as a broad-leaved species, had a thick litter layer and, therefore, a higher soil water content. The soil water content of the mixed forest site was $12.63 \%$, being $8.16 \%$ lower than that of the R. pseudoacacia stand, which might have been caused by mulching. Soil water content followed the order R. pseudoacacia $>$ mixed forest $>$ L. gmelinii $>$ P. koraiensis $>$ P. tabulaeformis. Generally, the values first increased and then decreased with increasing soil depth, most likely because of evaporation in the $0-40-\mathrm{cm}$ soil layer. With increasing soil depth, evaporation decreased, resulting in a higher soil water content. At $60-100 \mathrm{~cm}$, the soil water content decreased with increasing soil depth, which may be due to the decreased water infiltration into the deeper soil layers. Similarly, the soil water storage significantly differed among the five forest sites (Figure 7). Similar to the variation patterns of soil water content, soil water storage is also affected by soil bulk density [43]. The R. pseudoacacia stand had the largest soil water storage $(178.9 \mathrm{~mm})$, which was $43.9 \%$ higher than that of the P. tabulaeformis stand $(124.3 \mathrm{~mm})$, which showed the lowest value (Figure 7). Soil water storage followed the order R. pseudoacacia $>$ mixed forest $>$ L. gmelinii $>$ P. koraiensis $>$ P. tabulaeformis. Cao et al. also found that the soil moisture under broad-leaved deciduous forest was higher than that under evergreen coniferous forest, most likely because of the high shading effect of broad-leaved tree species, lowering soil evaporation [44]. However, the five forest types could also absorb soil moisture in different soil layers, resulting in differences in soil moisture. Because the data of soil moisture in this study were from June to August with more precipitation, the above explanation may be biased. Long-term measurements on soil moisture dynamics and evapotranspiration are needed, in order to gain a better understanding of the soil water changes on different species. 


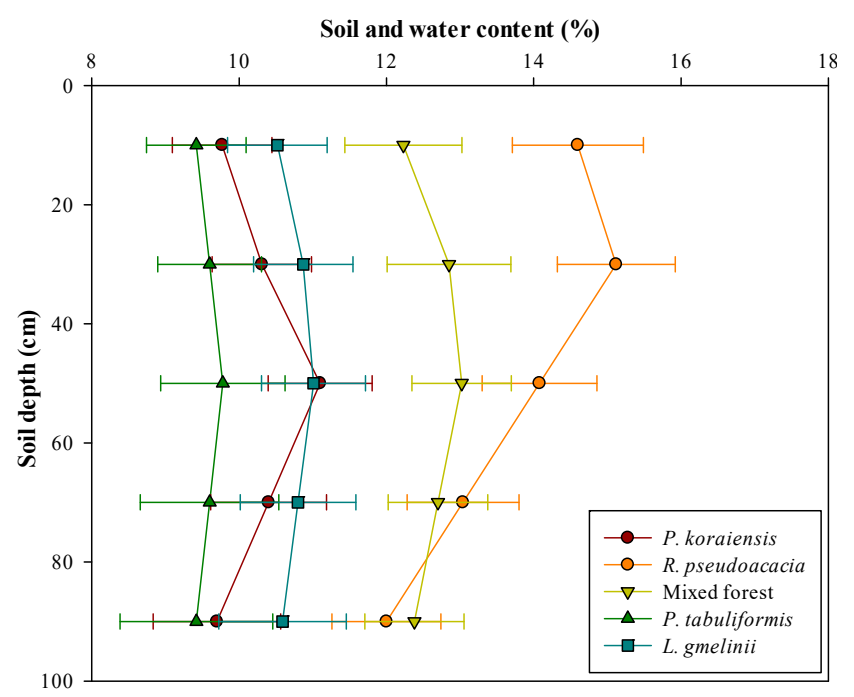

Figure 6. Variation in soil water content under different forest types in northeastern China.

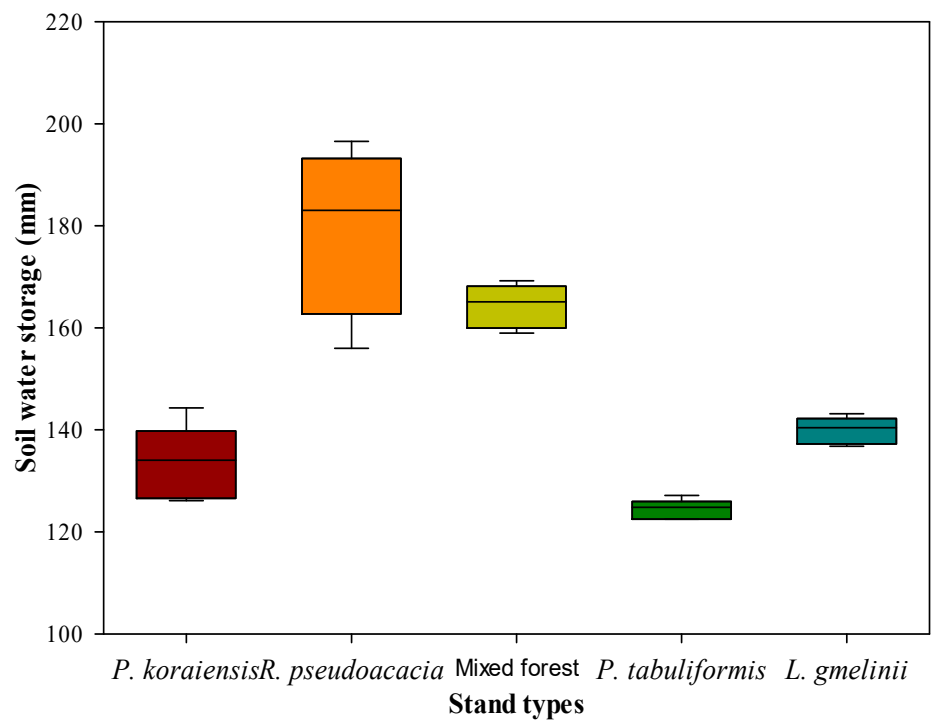

Figure 7. Variation in soil water storage under different forest types in northeastern China.

\subsection{Variation in Soil Organic Matter under Different Forest Types}

Soil organic matter is an important indicator of the soil nutrient content [45]. The levels of soil organic matter differed among the five forest types (Figure 8). In the R. pseudoacacia, mixed forest, and L. gmelinii sites, the levels were $0.23 \%, 0.22 \%$, and $0.22 \%$, respectively, without significant differences. In the P. koraiensis site, the soil organic matter level was thelowest one $(0.17 \%)$, which was $23.47 \%$ lower than that of the R. pseudoacacia site, while the P. tabulaeformis site showed a content of $0.19 \%$, which was $11.76 \%$ higher than that of P. koraiensis and $21.73 \%$ lower than that of R. pseudoacacia. Most likely, this is because $P$. koraiensis and P. tabulaeformis are evergreen species and produce low amounts of litter, which only decomposes slowly; in contrast, R. pseudoacacia, a broad-leaved species, produces large amounts of litter with a high organic matter content. In natural forest ecosystems, the decomposition of litter into soil organic matter may be the main reason for the increase in soil organic matter [45]. In our study, the five forest types had a stand age of about 50 years, with a similar length of time to accumulate organic matter. The levels decreased with soil depth, most likely because of the lower litter amount in the deeper soil layers. Similar results have been found previously [46]. 


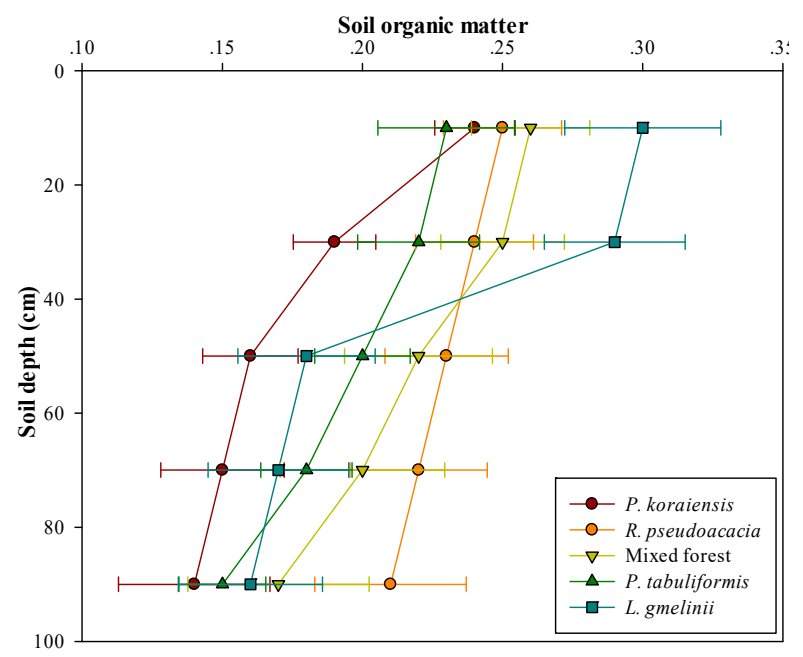

Figure 8. Variation in soil organic matter under different forest types in northeastern China.

\subsection{Soil and Water Conservation Function}

The value of the comprehensive evaluation directly reflects the water conservation capacity of different forest types [47]. The larger the comprehensive evaluation value, the higher the effect of the corresponding water conservation capacity [48]. According to Table 3, the conservation function of the five forest sites followed the order R. pseudoacacia $(0.8215)>$ mixed forest $(0.8043)>$ L. gmelinii $(0.6875)>$ P. koraiensis $(0.4912)>P$. tabulaeformis $(0.3891)$. This indicates that broad-leaved or mixed forest stands have a better water conservation function than coniferous stands. Regarding the indicator value, the greater the correlation value of the evaluation indicators, the greater the impact of the corresponding indicators on the water conservation function. The order of the correlation degree was $\mathrm{BL}_{\mathrm{wr}}(0.7046)>$ $\mathrm{L}_{\mathrm{wc}}(0.5772)>\mathrm{L}_{\mathrm{wr}}(0.5392)>\operatorname{SWC}(0.5378)>\mathrm{I}_{\mathrm{r}}(0.5128)>\mathrm{SWS}(0.4874)>\mathrm{SOM}(0.3333)$. The BL $\mathrm{L}_{\mathrm{wr}}$ is one of the most important factors affecting water conservation, while the soil nutrient content has the least influence. Broad-leaved or mixed forest stands are, based on our results, ideal for the study region in terms of water storage. This implies that broad-leaved species should preferentially be planted to enhance water conservation. In the initial phases of such plantings, irrigation can be applied to increase canopy biomass and achieve the maximum water conservation capacity.

Table 3. Correlation degrees and correlation coefficients of each evaluation index. $\mathrm{BL}_{\mathrm{wr}}, \mathrm{L}_{\mathrm{wc}}, \mathrm{L}_{\mathrm{wr}}, \mathrm{I}_{\mathrm{r}}$, SWC, SWS, SOM are the water-holding rate of branches and leaves, water-holding capacity of litter, water absorption rate of litter, infiltration rate of soil, soil and water content, soil water storage, and soil organic matter, respectively. The parameter ri and Wi indicate the degree of gray correlation and the coefficient of variation, respectively.

\begin{tabular}{ccccccccc}
\hline Forest Types & $\mathbf{B L}_{\mathbf{w r}}$ & $\mathbf{L}_{\mathbf{w c}}$ & $\mathbf{L}_{\mathbf{w r}}$ & $\mathbf{I}_{\mathbf{r}}$ & $\mathbf{S W C}$ & $\mathbf{S W S}$ & SOM & $\mathbf{G ( k )}$ \\
\hline P. koraiensis & 0.5115 & 0.413 & 0.555 & 0.4898 & 0.4483 & 0.5496 & 0.4483 & 0.491199 \\
R. pseudoacacia & 0.8864 & 0.925 & 0.7981 & 0.8142 & 0.8513 & 0.6498 & 0.4074 & 0.821541 \\
Mixed forest & 0.8005 & 0.8595 & 0.8477 & 0.734 & 0.9244 & 0.7251 & 0.3333 & 0.804347 \\
P. tabuliformis & 0.3333 & 0.3576 & 0.5286 & 0.3388 & 0.3538 & 0.4026 & 0.3538 & 0.389099 \\
L. gmelinii & 0.7489 & 0.6653 & 0.7106 & 0.8477 & 0.5475 & 0.6162 & 0.4797 & 0.687501 \\
ri & 0.7046 & 0.5772 & 0.5392 & 0.5128 & 0.5378 & 0.4874 & 0.3333 & - \\
Wi & 0.2075 & 0.2125 & 0.2018 & 0.1177 & 0.1172 & 0.1073 & 0.036 & - \\
\hline
\end{tabular}

\section{Conclusions}

Based on our results, the R. pseudoacacia stand showed the highest soil water storage capacity of $178.9 \mathrm{~mm}$, while the lowest one was found for the P. tabulaeformis stand $(124.3 \mathrm{~mm})$. Soil water storage and water conservation capacity of the five forest sites followed the order R. pseudoacacia $>$ mixed forest $>$ L. gmelinii $>$ P. koraiensis $>$ P. tabulaeformis. We found significant differences in the water 
conservation capacity among the five forest types. The main factors affecting the water conservation of a stand are canopy water-holding capacity and litter water-holding capacity; broad-leaved and mixed forest stands had a higher water absorption capacity than coniferous stands. In the initial phases, the canopy biomass of a stand needs to be increased to achieve optimal results. The most suitable forest types in the study area are R. pseudoacacia or mixed forest stands; ideally, coniferous forests with a low water conservation capacity are transformed into R. pseudoacacia stands to effectively improve water conservation in the area., Long-term measurements on water conservation function of forests soil moisture in future are needed, since only three months of data were used in this study.

Author Contributions: X.Z. wrote the paper; L.C. conceived and designed the experiments; W.G., X.Y. and Y.K. analyzed the data.

Funding: This research received no external funding.

Acknowledgments: This research was supported by the National Science and Technology Support Project (2015BAD07B03).

Conflicts of Interest: The authors declare no conflict of interest.

\section{References}

1. Zhao, G.; Gao, H.; Naz, B.S.; Kao, S.C.; Voision, N. Integrating a reservoir regulation scheme into a spatially distributed hydrological model. Adv. Water Resour. 2016, 98, 16-31. [CrossRef]

2. Glin'Skalewczuk, K. Water quality dynamics of oxbow lakes in young glacial landscape of NE Poland in relation to their hydrological connectivity. Ecol. Eng. 2009, 35, 25-37. [CrossRef]

3. Brooks, B.W.; Riley, T.M.; Taylor, R.D. Water Quality of Effluent-dominated Ecosystems: Ecotoxicological, Hydrological, and Management Considerations. Hydrobiologia 2006, 556, 365-379. [CrossRef]

4. Cook, L.M.; Samaras, C.; Vanbriesen, J.M. A mathematical model to plan for long-term effects of water conservation choices on dry weather wastewater flows and concentrations. J. Environ. Manag. 2018, 206, 684-697. [CrossRef] [PubMed]

5. Zolin, C.A.; Folegatti, M.V.; Mingoti, R.; Pailino, J. The first Brazilian municipal initiative of payments for environmental services and its potential for soil conservation. Agric. Water Manag. 2014, 137, 75-83. [CrossRef]

6. Gonzales, P.; Ajami, N. Social and Structural Patterns of Drought-Related Water Conservation and Rebound. Water Resour. Res. 2017, 53, 253-262. [CrossRef]

7. Ramulifho, P.A.; Riversmoore, N.A.; Dallas, H.F.; Foord, S.H. A conceptual framework towards more holistic freshwater conservation planning through incorporation of stream connectivity and thermal vulnerability. J. Hydrol. 2018, 556, 173-181. [CrossRef]

8. Liu, C.; He, N.; Zhang, J.; Li, Y.; Wang, Q.F.; Sack, L.; Yu, G.R. Data from: Variation of stomatal traits from cold-temperate to tropical forests and association with water use efficiency. Funct. Ecol. 2017, 32, 20-28. [CrossRef]

9. Geedicke, I.; Oldeland, J.; Leishman, M.R. Urban storm water run-off promotes compression of saltmarshes by freshwater plants and mangrove forests. Sci. Total Environ. 2018, 637-638, 137-144. [CrossRef]

10. Ramírez, B.H.; Ploeg, M.V.D.; Teuling, A.J.; Ganzelveld, L.; Leemans, R. Tropical Montane Cloud Forests in the Orinoco river basin: The role of soil organic layers in water storage and release. Geoderma 2017, 298, 14-26. [CrossRef]

11. Vahmani, P.; Jones, A.D. Water conservation benefits of urban heat mitigation. Nat. Commun. 2017, 8, 1072. [CrossRef] [PubMed]

12. Nascimbene, J.; Spitale, D. Patterns of beta-diversity along elevational gradients inform epiphyte conservation in alpine forests under a climate change scenario. Biol. Conserv. 2017, 216, 26-32. [CrossRef]

13. Brandt, J.S.; Allendorf, T.; Radeloff, V.; Brooks, J. Effects of national forest-management regimes on unprotected forests of the Himalaya. Conserv. Biol. 2017, 31, 1271-1282. [CrossRef] [PubMed]

14. Wan, J.Z.; Wang, C.J.; Yu, F.H. Spatial conservation prioritization for dominant tree species of Chinese forest communities under climate change. Clim. Chang. 2017, 144, 303-316. [CrossRef] 
15. Monroy-Ortiz, C.; García-Moya, E.; Romero-Manzanares, A.; Luna-Cavazos, M.; Monroy, R. Traditional and formal ecological knowledge to assess harvesting and conservation of a Mexican Tropical Dry Forest. J. Environ. Manag. 2018, 214, 56-65. [CrossRef]

16. Chang, C.T.; Wang, L.J.; Huang, J.C.; Liu, C.P.; Wang, C.P.; Lin, N.H.; Wang, L.X.; Lin, T.C. Precipitation controls on nutrient budgets in subtropical and tropical forests and the implications under changing climate. Adv. Water Resour. 2017, 103, 44-50. [CrossRef]

17. Spring, D.A.; Croft, L.; Bond, N.R.; Cunningham, S.C.; Mac Nally, R.; Kompas, T. Institutional impediments to conservation of freshwater dependent ecosystems. Sci. Total Environ. 2017, 621, 407. [CrossRef]

18. Taki, Y.; Shigeo, K.; Kazunori, S.; Ryoi, G. Correlation between degree of white matter hyperintensities and global gray matter volume decline rate. Neuroradiology 2011, 53, 397-403. [CrossRef]

19. Coyne, R.; Corsi, A.; Owen, B.J. Cross-correlation method for intermediate-duration gravitational wave searches associated with gamma-ray bursts. Phys. Rev. D 2015, 93, 104059. [CrossRef]

20. Wohlfahrt, G.; Gu, L. The many meanings of gross photosynthesis and their implication for photosynthesis research from leaf to globe. Plant. Cell Environ. 2015, 38, 2500-2507. [CrossRef]

21. Feller, U. Drought stress and carbon assimilation in a warming climate: reversible and irreversible impacts. J. Plant. Physiol. 2016, 203, 84-94. [CrossRef]

22. Ren, G.; Zhou, G. Canopy Rainfall Redistribution for Various Major Forest Vegetation Types in Eastern Liaoning Mountainous Region. Liaoning Agric. Sci. 2002, 1, 5-9. [CrossRef]

23. Morin, R.S.; Liebhold, A.M.; Gottschalk, K.W.; Woodall, C.W.; Twardus, D.B.; White, R.L.; Horsley, S.B.; Ristau, T.E. Analysis of forest health monitoring surveys on the allegheny national forest (1998-2001). Nature 2006, 74, 538-543. [CrossRef]

24. Meek, B.D.; Rechel, E.R.; Carter, L.M.; Detar, W.R.; Urie, A.L. Infiltration rate of a sandy loam soil: effects of traffic, tillage and plant roots. Soil Sci. Soc. Am. J. 1992, 56, 908. [CrossRef]

25. Kikuchi, M.; Syudo, A.; Hukumori, M.; Naito, C.; Sawai, J. Changes in aquatic toxicity of potassium dichromate as a function of water quality parameters. Chemosphere 2017, 170, 113-117. [CrossRef]

26. Walker, J.P.; Willgoose, G.R.; Kalma, J.D. In situ measurement of soil moisture: A comparison of techniques. J. Hydrol. 2004, 293, 85-99. [CrossRef]

27. Yun, L. Fault diagnosis method based on gray correlation and evidence theory. J. Electron. Meas. Instrum. 2009, 2009, 68-72. [CrossRef]

28. Melody, J.L.; Lonergan, S.M.; Rowe, L.J.; Huiatt, T.W.; Mayes, M.S.; Huff-Lonergan, E. Early postmortem biochemical factors influence tenderness and water-holding capacity of three porcine muscles. J. Anim. Sci. 2004, 82, 1195-1205. [CrossRef]

29. Bouton, P.E.; Harris, P.V.; Shorthose, W.R. Effect of ultimate $\mathrm{pH}$ upon the water-holding capacity and tenderness of mutton. J. Food Sci. 1971, 36, 435-439. [CrossRef]

30. Kern, J.S. Geographic Patterns of Soil Water-Holding Capacity in the Contiguous United States. Soil Sci. Soc. Am. J. 1995, 59, 1126-1133. [CrossRef]

31. Dunlop, M.W.; Blackall, P.J.; Stuetz, R.M. Water addition, evaporation and water holding capacity of poultry litter. Sci. Total Environ. 2015, 538, 979-985. [CrossRef]

32. Harris, M.R.; Lamb, D.; Erskine, P.D. An investigation into the possible inhibitory effects of white cypress pine (Callitris glaucophylla) litter on the germination and growth of associated ground cover species. Aust. J. Bot. 2003, 51, 93-102. [CrossRef]

33. Milly, P.C.D.; Dunne, K.A. Sensitivity of the Global Water Cycle to the Water-Holding Capacity of Land. J. Clim. 1994, 7, 506-526. [CrossRef]

34. Boyce1, R.L.; Mccune, D.C. Water holdup capacity and residence time of red spruce and balsam fir branches. Trees 1992, 6, 10-27. [CrossRef]

35. Tsegaye, T.D.; Ranatunga, T.D.; Reddy, K.C. Variation of Soil Dielectric Constant, Moisture Holding Capacity, and Nitrate-Nitrogen as Influenced by Application of Fresh and Compost Poultry Litter on a Decatur Silt Loam Soil. J. Sustain. Agric. 2003, 22, 55-73. [CrossRef]

36. Park, A.; Friesen, P.; Serrud, A.A.S. Comparative water fluxes through leaf litter of tropical plantation trees and the invasive grass Saccharum spontaneum in the Republic of Panama. J. Hydrol. 2010, 383, 167-178. [CrossRef]

37. Cabrera, M.L.; Chiang, S.C. Water content effect on denitrification and ammonia volatilization in poultry Litter. Soil Sci. Soc. Am. J. 1994, 58, 811-816. [CrossRef] 
38. Martin, D.A.; Moody, J.A. Comparison of soil infiltration rates in burned and unburned mountainous watersheds. Hydrol. Process. 2010, 15, 323-331. [CrossRef]

39. Dunkerley, D.L. Infiltration rates and soil moisture in a groved mulga community near Alice Springs, arid central Australia: Evidence for complex internal rainwater redistribution in a runoff-Runon landscape. J. Arid Environ. 2002, 51, 199-219. [CrossRef]

40. Dunkerley, D.D. Systematic variation of soil infiltration rates within and between the components of the vegetation mosaic in an Australian desert landscape. Hydrol. Process. 2002, 16, 119-131. [CrossRef]

41. Appels, W.M.; Coles, A.E.; Mcdonnell, J.J. Infiltration into frozen soil: From core-scale dynamics to hillslope-scale connectivity. Hydrol. Process. 2018, 32. [CrossRef]

42. López-Vicente, M.; Álvarez, S. Stability and patterns of topsoil water content in rainfed vineyards, olive groves, and cereal fields under different soil and tillage conditions. Agric. Water Manag. 2018, 201, 167-176. [CrossRef]

43. Sun, M.; Ren, A.X.; Gao, Z.Q.; Wang, P.R.; Xue, L.Z.; Lei, M.M. Long-term evaluation of tillage methods in fallow season for soil water storage, wheat yield and water use efficiency in semiarid southeast of the Loess Plateau. Field Crop. Res. 2018, 218, 24-32. [CrossRef]

44. Cao, R.; Jia, X.; Huang, L.; Zhu, Y.J.; Wu, L.H.; Shao, M.A. Deep soil water storage varies with vegetation type and rainfall amount in the Loess Plateau of China. Sci. Rep. 2018, 8, 12346. [CrossRef]

45. Rasmussen, C.; Heckman, K.; Wieder, W.R.; Keiluweit, M.; Lawrence, C.R.; Berhe, A.A.; Blankinship, J.C.; Crow, S.E.; Druhan, J.L.; Pries, C.E.H.; et al. Beyond clay: Towards an improved set of variables for predicting soil organic matter content. Biogeochemistry 2018, 137, 297-306. [CrossRef]

46. Pellitier, P.T.; Zak, D.R. Ectomycorrhizal fungi and the enzymatic liberation of nitrogen from soil organic matter: Why evolutionary history matters. New Phytol. 2018, 217, 68-73. [CrossRef]

47. Tian, J.; He, N.; Hale, L.; Niu, S.L.; Liu, Y.; Blagodatskaya, E.; Kuzyakov, Y.; Gao, Q.; Zhou, J.Z. Soil organic matter availability and climate drive latitudinal patterns in bacterial diversity from tropical to cold temperate forests. Funct. Ecol. 2018. [CrossRef]

48. Cui, M.; Zhang, Y.C. Application of Markov chain approach for multi-attributes dynamic software reliability assessment under both AHP and gray correlation methods. Int. J. Mod. Phys. C 2018, 29, 1840008. [CrossRef]

(C) 2019 by the authors. Licensee MDPI, Basel, Switzerland. This article is an open access article distributed under the terms and conditions of the Creative Commons Attribution (CC BY) license (http://creativecommons.org/licenses/by/4.0/). 